\title{
Evaluation of Micro-Crack Incidence and their Influence on the Corrosion Resistance of Steel Coated with Different Chromium Thicknesses
}

\author{
Santos, B. A. F.;* Serenário, M. E. D.; Pinto, D. L. M. F.; Simões, T. A.; \\ Malafaia, A. M. S.; Bueno, A. H. S.
}

Rev. Virtual Quim., 2019, 11 (1), 264-274. Data de publicação na Web: 7 de fevereiro de 2019

http://rvq.sbq.org.br

\section{Avaliação da Incidência de Micro Trincas e suas Influências na Resistência à Corrosão do Aço Revestido com Diferentes Espessuras de Cromo}

\begin{abstract}
Resumo: Revestimentos de cromo são frequentemente utilizados para aplicação onde a corrosão e desgaste estão combinados. 0 objetivo deste trabalho foi avaliar a incidência de micro trincas e a resistência a corrosão por pites de cinco diferentes espessuras de revestimento de cromo aplicadas sobre o aço C45K. Estes revestimentos de cromo foram aplicados através do processo de eletrólise. Cinco amostras foram preparadas com espessuras de 0 a $34 \mu \mathrm{m}$. Os revestimentos foram caracterizados através da microscopia eletrônica de varredura (MEV), microscopia ótica (MO) e microdureza. A resistência à corrosão foi avaliada através de ensaios eletroquímicos de curva de polarização e potencial vs. tempo em uma solução de $3.5 \%$ de $\mathrm{NaCl}$. Ensaios em câmara com névoa salina também foram realizados. Os resultados mostraram que a medida que se aumenta a camada de cromo obtém-se uma maior resistência à corrosão por barreira, isso é na superfície das amostras. Entretanto os ensaios de salt-spray mostraram que todas as amostras apresentaram corrosão localizada após 120 horas. Através das imagens de MEV ficou claro o desenvolvimento das micro trincas após os ensaios de polarização. A incidência de micro trincas é especulada como um fator determinante para a degradação da superfície, uma vez que os íons cloreto tem facilidade em penetrar entre as trincas, causando corrosão localizada no substrato.
\end{abstract}

Palavras-chave: Revestimentos de cromo; micro trincas; corrosão localizada; câmara de névoa salina; polarização anódica.

\begin{abstract}
Hard chromium coatings are often used for applications where corrosion resistance and wear degradation protection are need. The aim of this study was to evaluate the incidence of micro-cracks networks and corrosion resistance of different thicknesses of chromium coatings deposited on C45K steel. The coatings were applied through an electrolysis process. Five samples were prepared with different chromium thicknesses in a ranging from 0 to $34 \mu \mathrm{m}$. The coatings were characterized thought optical (OM) and scanning electron microscope (SEM) and Vickers micro-hardness. Corrosion resistance was evaluated by anodic polarization and potential versus time in a solution of $3.5 \% \mathrm{NaCl}$. Tests in the salt-spray chamber were also performed. The results show that the progressive increase of chromium thickness drastically improves the corrosion resistance barrier on the sample surfaces. Through the SEM magnifications, it was clearly observable that the micro-crack networks developed after the polarization tests. However, the salt spray chamber results demonstrate that all samples presented localized corrosion after 120 hours. The incidence of microcracking is speculated as the determining factor for surface degradation, since chloride ions can easily penetrate the cracks, causing localized corrosion on the bulk material.
\end{abstract}

Keywords: Hard chromium coatings; micro-cracks; localized corrosion; salt spray chamber; anodic polarization.

\footnotetext{
* Universidade Federal de São João del-Rei, Mechanical Engineering Department, Praça Frei Orlando, CEP 36307-352 São João Del Rei-MG, Brazil.

$M$ bernardo.a.fs@hotmail.com

DOI: $\underline{10.21577 / 1984-6835.20190019}$
} 


\title{
Evaluation of Micro-Crack Incidence and their Influence on the Corrosion Resistance of Steel Coated with Different Chromium Thicknesses
}

\author{
Bernardo Augusto F. Santos, ${ }^{a, *}$ Maria E. D. Serenário, ${ }^{a}$ Diego L. M. F. \\ Pinto, ${ }^{a}$ Thiago A. Simões, ${ }^{b}$ Artur M. S. Malafaia, a Alysson H. S. Bueno ${ }^{a}$ \\ a Universidade Federal de São João del-Rei, Mechanical Engineering Department, Praça Frei \\ Orlando, CEP 36307-352 São João Del Rei-MG, Brazil \\ ${ }^{\text {b } ~ U n i v e r s i d a d e ~ F e d e r a l ~ d a ~ P a r a i ́ b a, ~ P o s t g r a d u a t e ~ P r o g r a m ~ i n ~ S c i e n c e ~ a n d ~ E n g i n e e r i n g ~ o f ~}$ \\ Material, João Pessoa-PB, Brazil. \\ * bernardo.a.fs@hotmail.com
}

\section{Introduction}

\section{Materials and Methods}

\subsection{Materials}

2.2. Microscopy analysis

2.3. Electrochemical tests

2.4. Salt spray chamber

\section{Results and Discussion}

\section{Conclusions}

\section{Introduction}

Hard chromium has been widely used in applications which requires resistance to sliding wear. ${ }^{1}$ The hard chromium plating is not only price competitive, but has several important intrinsic properties related to high hardness, good corrosion resistance and a self-leveling effect. ${ }^{2}$ The combination of these properties enables the use of hard chromium in applications where conditions require high hardness, low friction, low wear and high corrosion resistance. Piston rods for dampers, piston rings and cylinder liners, hydraulic equipment, shafts, rollers for rolling of metals and metal molds are devices in which hard chromium coatings are often applied. ${ }^{3}$

Although chromium has been proved as a good element to be applied in many devices, it also has some harmful effects both for human body and the environment. Literature has shown that the interaction of chromium and some the media involved has the potential to release metal ions, which may pollute water and soils. Moreover, when chromium is used in medical devices that are high wear requested inside the body, that process might release wear debris and/ or 
metal ions from the alloys that might be trigger several diseases. ${ }^{4-6}$

Chromium is used as a coating when there is a desire to associate corrosion resistance with low wear rate. ${ }^{7}$ However, due to the incidence of micro-cracks arising from chromium coating application, the coated pieces often shows film degradation and high incidence of substrate localized corrosion. Chromium coating applications in devices that are exposed on seashore environments with great amounts of salts have presented premature failures due to chloride penetration into the micro-cracks. The problem has been explored by researchers studying new techniques and ways to deal with this issue ${ }^{8}$. However, there is a gap on optimal coating conditions to avoid overall degradation of the coated piece.

The microstructure and morphology have an important role on the coatings lifespan. The aim of this study was to evaluate the incidence of micro-cracks and corrosion resistance of steel $\mathrm{C} 45 \mathrm{~K}$ coated with different layers of chromium immersed in $3.5 \% \mathrm{NaCl}$. Comparisons between samples before and after testing by surface morphology characterization were performed.

\section{Materials and Methods}

\subsection{Materials}

The materials were evaluated as received by the company Magneti Marelli Cofap. The process used for the application of the chromium layer was by electrolysis. The five thicknesses chosen were set based in the ones that are most used in coating damping rods in automobile industry.

Table 1 shows hardness of the $\mathrm{C} 45 \mathrm{~K}$ carbon steel samples coated with different thicknesses of chromium.

Table 1. Specification of the chromium coating thicknesses and its hardness

\begin{tabular}{ccccccc}
\hline $\begin{array}{c}\text { Chromium } \\
\text { thicknesses }\end{array}$ & $0 \mu \mathrm{m}$ & $\begin{array}{c}11-12 \\
\mu \mathrm{m}\end{array}$ & $\begin{array}{c}13-16 \\
\mu \mathrm{m}\end{array}$ & $\begin{array}{c}19-20 \\
\mu \mathrm{m}\end{array}$ & $\begin{array}{c}20-22 \\
\mu \mathrm{m}\end{array}$ & $\begin{array}{c}29-34 \\
\text { Vickers }\end{array}$ \\
$\begin{array}{c}\text { microhardnes } \\
\text { s }\end{array}$ & $\begin{array}{c}240 \\
\mathrm{HV}\end{array}$ & $833 \mathrm{HV}$ & $736 \mathrm{HV}$ & $659 \mathrm{HV}$ & $755 \mathrm{HV}$ & $790 \mathrm{HV}$ \\
\hline
\end{tabular}

\subsection{Microscopy analysis}

The microstructure of the coating was analyzed using an Olympus SC30 optical microscopy and a HITACHI TM3000 scanning electron microscopy. The tests were performed in the longitudinal direction before and after the electrochemical tests to evaluate localized corrosion of the substrate after the tests. Examinations were also performed in the transverse direction to evaluate the incidence of micro-cracks in the coating.

After the electrochemical tests on steel C45K coated with chrome, the surfaces of the samples were cleaned with cotton for subsequent degradation analyses.

\subsection{Eletrochemical tests}

The corrosion resistance was determined by potential over time and potentiodynamic method. In the test for measuring the potential over time, the electrodes of carbon steel $\mathrm{C} 45 \mathrm{~K}$ were immersed in $3.5 \% \mathrm{NaCl}$. The corrosion potentials were monitored twice daily for the first six days until stabilization.

Potentiostatic test was conducted for each sample in a solution $3.5 \% \mathrm{NaCl}$ naturally 
aerated. An exposed area of $0.25 \mathrm{~cm}^{2}$ was used for the anodic polarization test. The tests were conducted in a conventional threeelectrode electrochemical cell, at a scan rate of $0.001 \mathrm{~V} / \mathrm{s}$ using AUTOLAB PGSTAT 101 potentiostat. Saturated Calomel Electrode (SCE) and platinum electrode were used as reference and counter electrode, respectively. The working electrodes were C45K steel samples with and without chrome plating.

\subsection{Salt spray chamber}

For the test in salt spray chamber, samples were exposed to mist of a solution of $5 \% \mathrm{NaCl}$, $\mathrm{pH}$ between 6.5 and 7.2, at a temperature of $25^{\circ} \mathrm{C} \pm 2{ }^{\circ} \mathrm{C}$, in a position from $12^{\circ}$ to $20^{\circ}$ in relation to the vertical axis, according to ISO 9227: 2006-10. The tests were performed using Salt Spray Equilam SS600E. The samples remained in the chamber for $96 \mathrm{~h}$. The evaluation was made by visual examination of the surface morphology.

\section{Results and Discussion}

Figure 1 shows backscattered electron image of the samples as received and samples with chromium layer deposited with different thicknesses. Microscopic examination of the cross section provided as received exhibited a high incidence of micro-cracks and defects in chrome plating, as indicated by black arrows. The cracks appear independently of the $\mathrm{Cr}$ layer thickness. The increase of the thickness does not affect the visual look of samples. The extension of the cracks starts from the surface of the $\mathrm{Cr}$ layer up to the $\mathrm{C} 45 \mathrm{~K}$ substrate

For salt spray chamber tests, it was observed that chromium layer in the presence of chloride ions introduced points or localized corrosion areas, demonstrating that the ions penetrate through the discontinuities of the chromium coating. However, as the chromium layer increases, a higher resistance to corrosion can be observed, as shown in Figure 2.

The tests in salt spray chamber were conducted for 96 hours. The best performance is presented for coating of greater thickness, corresponding to 29 to $34 \mu \mathrm{m}$. No visual changes on the sample was seen after the tests. It was observed that durability was associated with an increase of the coating thickness. The thicker favors the blocking of chloride ions. However, after 120 hours all coatings present pitting corrosion. These results are consistent with the results presented by Beyragh, Khameneh and Norouzi ${ }^{9}$, where the large number of microcracks on the surface of the hard chromium favor the process of corrosion of the substrate. 

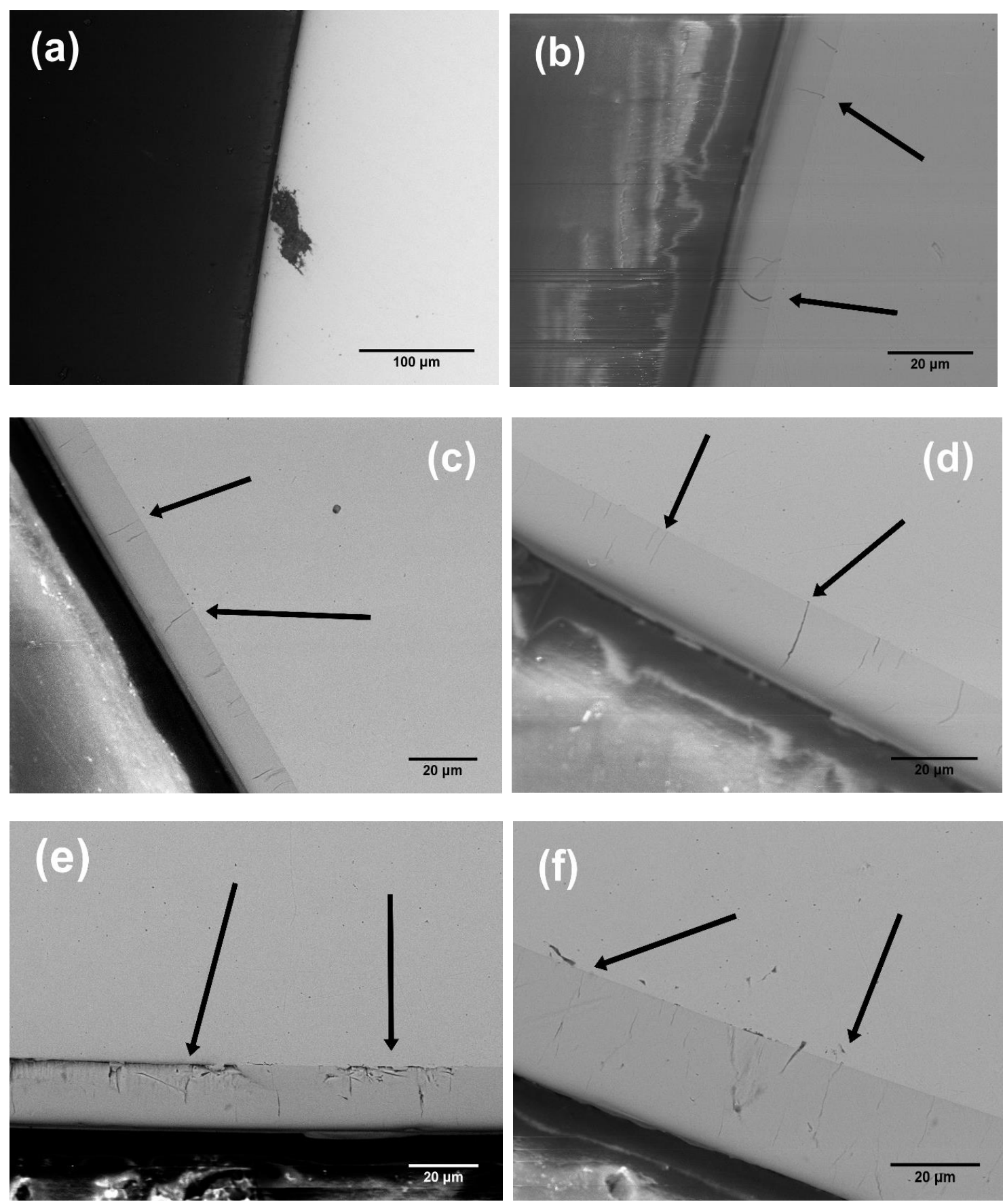

Figure 1. Backscattered electron image of the samples with and without chromium layer: (a) 0 $\mu \mathrm{m}$, (b) 11 to $12 \mu \mathrm{m}$, (c) 13 to $16 \mu \mathrm{m}$, (d) 19 to $20 \mu \mathrm{m}$ and (e) 20 to $22 \mu \mathrm{m}$ (f) 29 to $34 \mu \mathrm{m}$ 


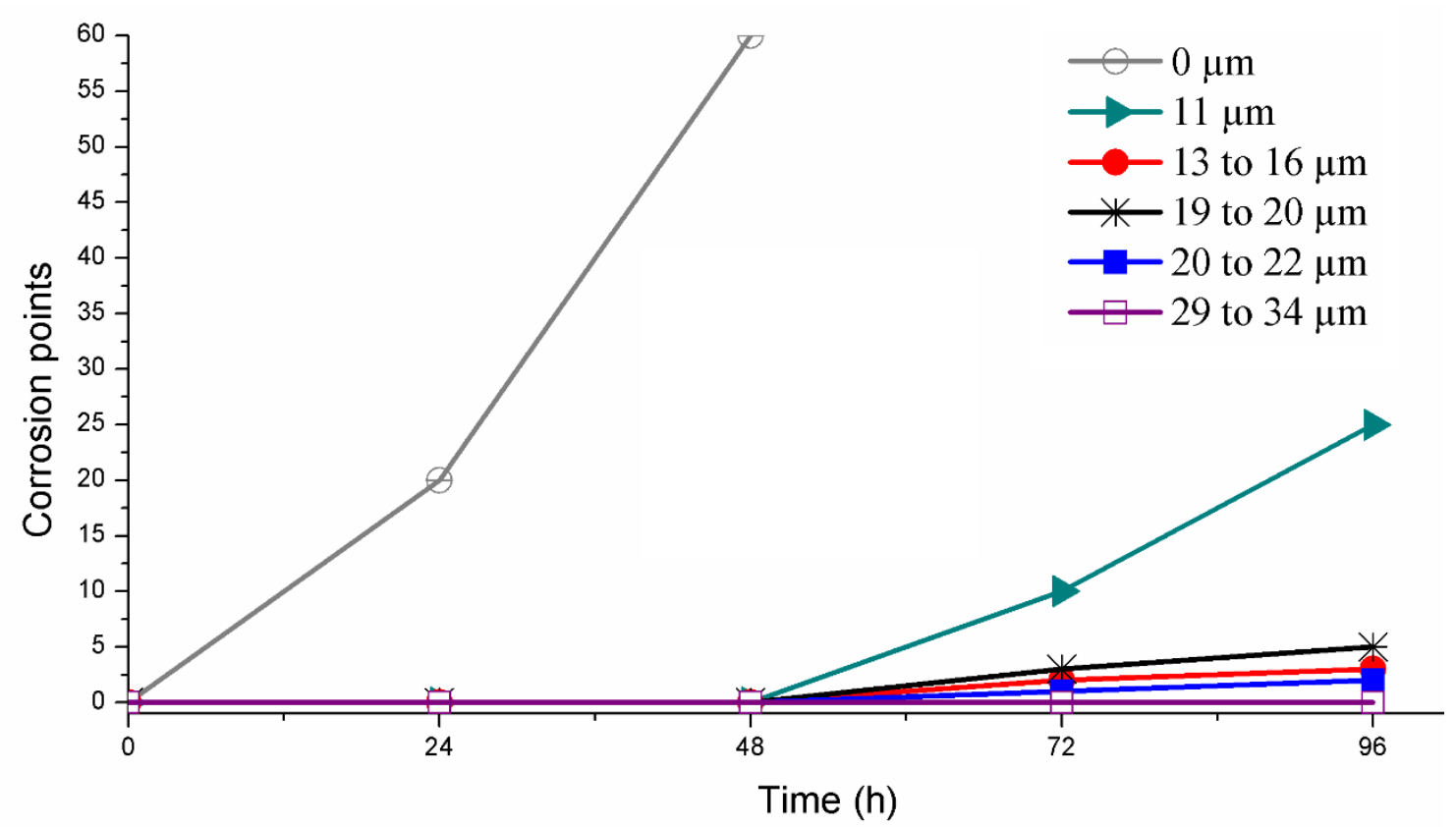

Figure 2. Appearance curves of corrosion points in time of exposure to salt spray chamber for C45K steel samples with and without coating of hard chrome

Figure 3 shows the anodic polarization curves obtained for each sample and Table 2 shows the main electrochemical parameters. Table 2 shows anodic current densities measures 50 to $100 \mathrm{mV}$ above the corrosion potential. These values of current densities can be compared since the results obtained using the same over-voltage.

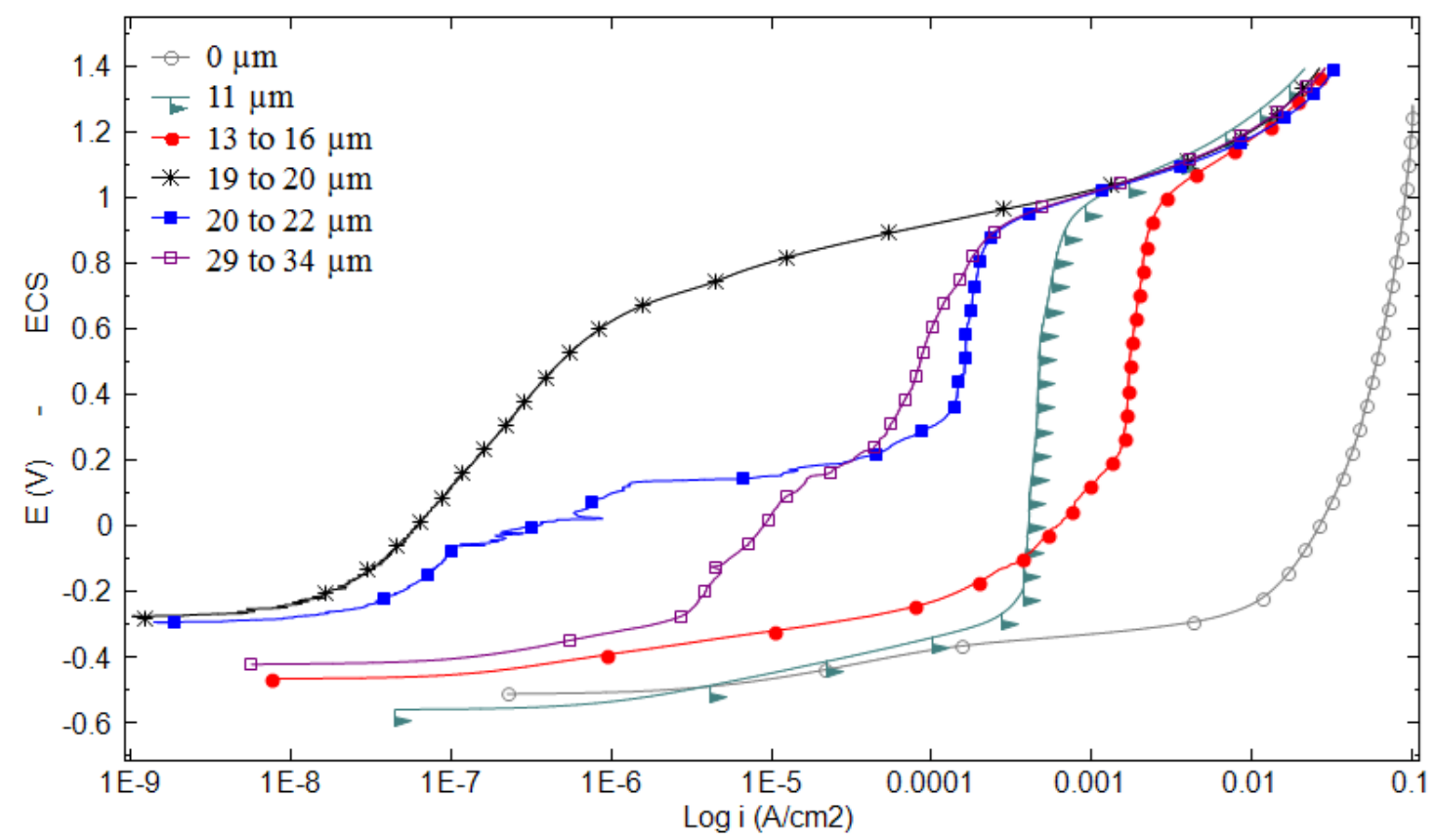

Figure 3. Anodic polarization curves for steel and non-C45K Chrome plated in $3.5 \% \mathrm{NaCl}$ solution, naturally aerated 
Table 2. Parameters for the test samples used in the polarization

\begin{tabular}{ccccc}
\hline & \multicolumn{2}{c}{$\mathbf{5 0} \mathbf{m V}$ Above Ecorr } & \multicolumn{2}{l}{$\mathbf{1 0 0} \mathbf{m V}$ Above Ecorr } \\
\cline { 2 - 5 } Thicknesses & \multicolumn{1}{c}{ Pot (mV) } & $\mathbf{i}(\mathbf{A})$ & Pot (mV) & $\mathbf{i}(\mathbf{A})$ \\
\hline $0 \mu \mathrm{m}$ & -454 & $1,15 \mathrm{E}-07$ & -405 & $4,09 \mathrm{E}-05$ \\
$11 \mu \mathrm{m}$ & -504 & $2,18 \mathrm{E}-06$ & -453 & $7,61 \mathrm{E}-06$ \\
$13-16 \mu \mathrm{m}$ & -430 & $2,15 \mathrm{E}-07$ & -380 & $2,00 \mathrm{E}-06$ \\
$19-20 \mu \mathrm{m}$ & -240 & $1,15 \mathrm{E}-08$ & -189 & $1,99 \mathrm{E}-08$ \\
$20-22 \mu \mathrm{m}$ & -250 & $3,60 \mathrm{E}-08$ & -200 & $8,63 \mathrm{E}-08$ \\
$29-34 \mu \mathrm{m}$ & -366 & $3,04 \mathrm{E}-07$ & -315 & $1,07 \mathrm{E}-06$ \\
\hline
\end{tabular}

Analyzing the curve, the steel without coating showed active dissolution, as expected. All the samples with coating suffered localized corrosion in the substrate. However, as the chromium layer increased, the specimens presented higher corrosion resistance. The samples with greater thicknesses presented a potential more positive and a lower anodic current density (Table 2). This occurred because the thicker of the film hinders the entry of chloride ions through the micro-cracks and coating defects.

The results are in agreement with Gentil, ${ }^{10}$ which concluded that metals or alloys of chromium, aluminum or stainless steel, passive in the air, have their passivity destroyed by chloride ions in points or localized areas. Thus, all samples, even those with a thicker chromium layer, suffered pitting corrosion. Corrosion probably occurred because the chloride penetrated through the micro-cracks and struck the surface of the C45K metal. This is confirmed by the results obtained by Beyragh, Khameneh and Norouzi, ${ }^{9}$ where corrosion in the coating, when more severe, is due to accelerated corrosion of the substrate. This corrosion is associated with infiltration of the solution between the interface of the substrate/ coating, through the micro-cracks and defects. Other works has proved that microcracks are caused by the production process, which is inherent. ${ }^{17}$
For Pardo et al., ${ }^{11}$ the resistance of the passive film is determined by the environmental conditions that chromium coated steels and stainless steels are exposed, as well as by the composition of the alloy. Under the action of aggressive ions, such as chloride anion, the local breakdown of passivity occurs, especially at sites of local with discontinuities, micro-cracks and pores causing pitting corrosion.

In addition, according to Gentil, ${ }^{10}$ pitting corrosion occurs since the anodic area is located at points where there was destruction of passivity and because these areas are very small relative to the cathode area, there will be accelerated corrosion at these points.

After the polarization tests, a longitudinal analysis of the specimens with light microscopy was conducted to assess the state of the chromium coating (Figures 4-9). The images before the polarization tests show none cracks on the sample surface. The images show that the coating after test presents a higher incidence of cracks, probably caused by accelerated anodic polarization and localized corrosion in the substrate. Plus, peeling occurred at low coating thicknesses. At higher thicknesses did not occur any detachment of the coating. However, the incidence of cracks was observed. 

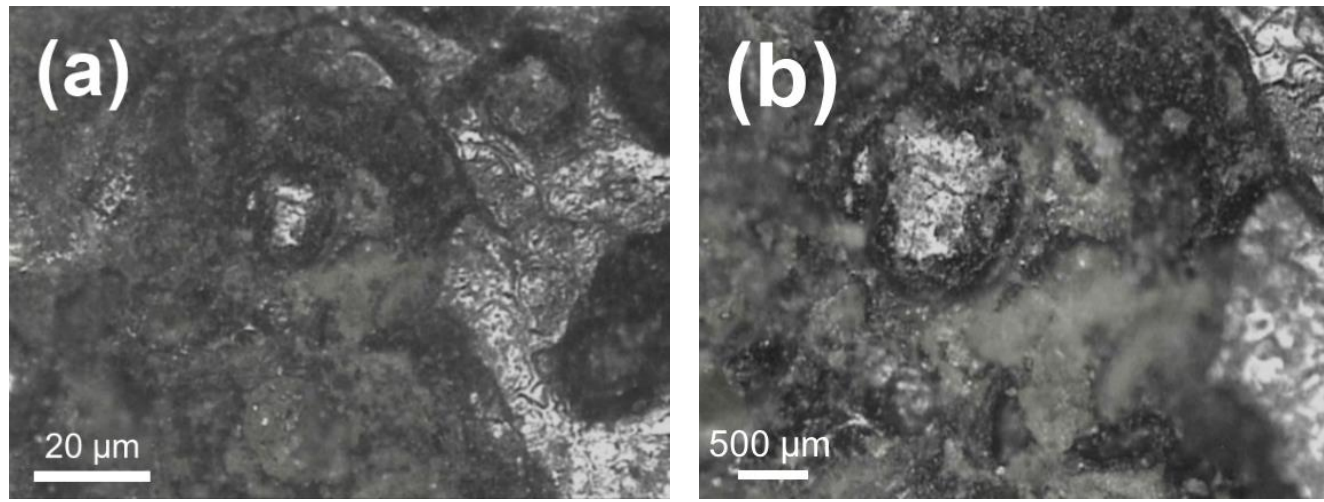

Figure 4. Optical microscopy after polarization test: Test specimen without chromium film, (a) 50x and (b) 100x magnification
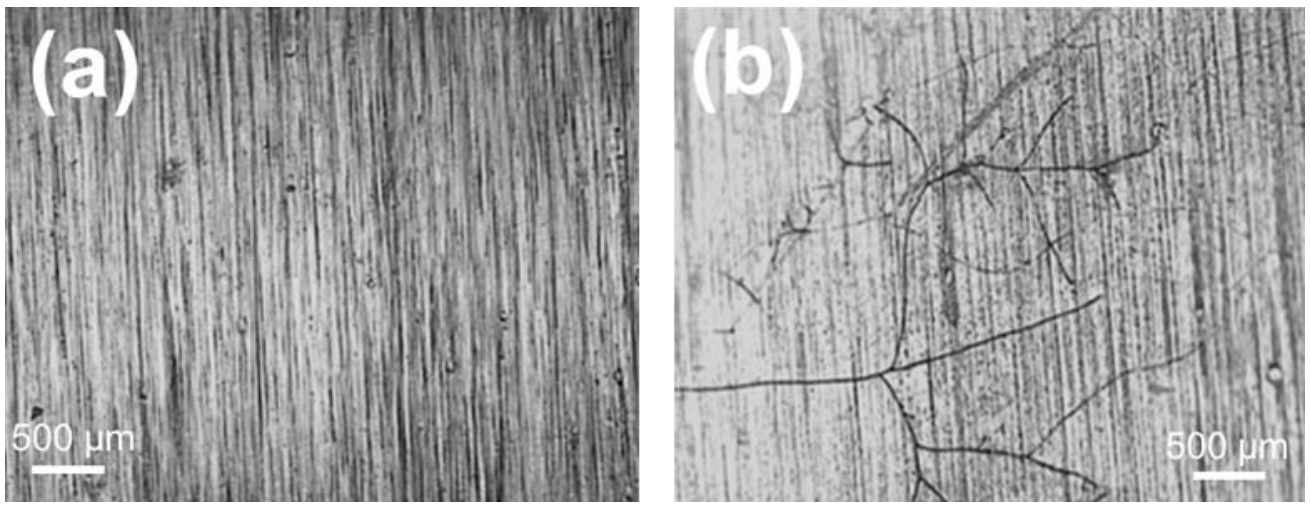

Figure 5. Optical microscopy before and after polarization test: Test specimen with a layer of chromium of $11 \mu \mathrm{m}$ to $12 \mu \mathrm{m}$, (a) before the test and (b) after test, magnification of $100 \mathrm{x}$
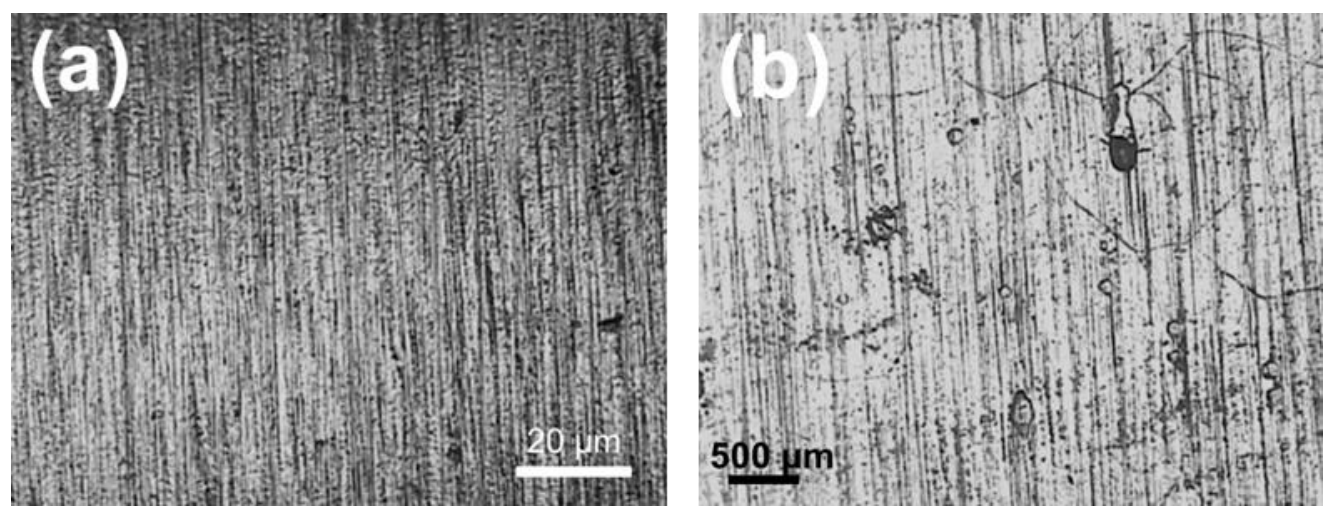

Figure 6. Optical microscopy before and after polarization test: Test specimen with a layer of chromium of $13 \mu \mathrm{m}$ to $16 \mu \mathrm{m}$, (a) before testing, and (b) after testing, magnification of 50x and $100 x$ respectively 

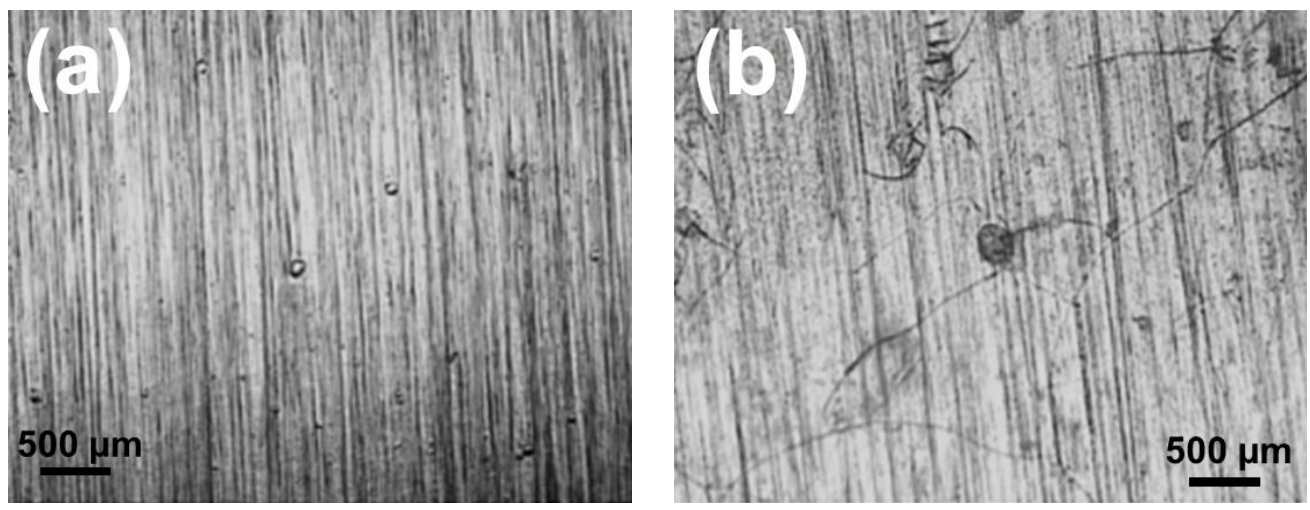

Figure 7. Optical microscopy before and after polarization test: Test specimen with a layer of chromium of $19 \mu \mathrm{m}$ to $20 \mu \mathrm{m}$, (a) before test, and (b) after testing 100x magnification
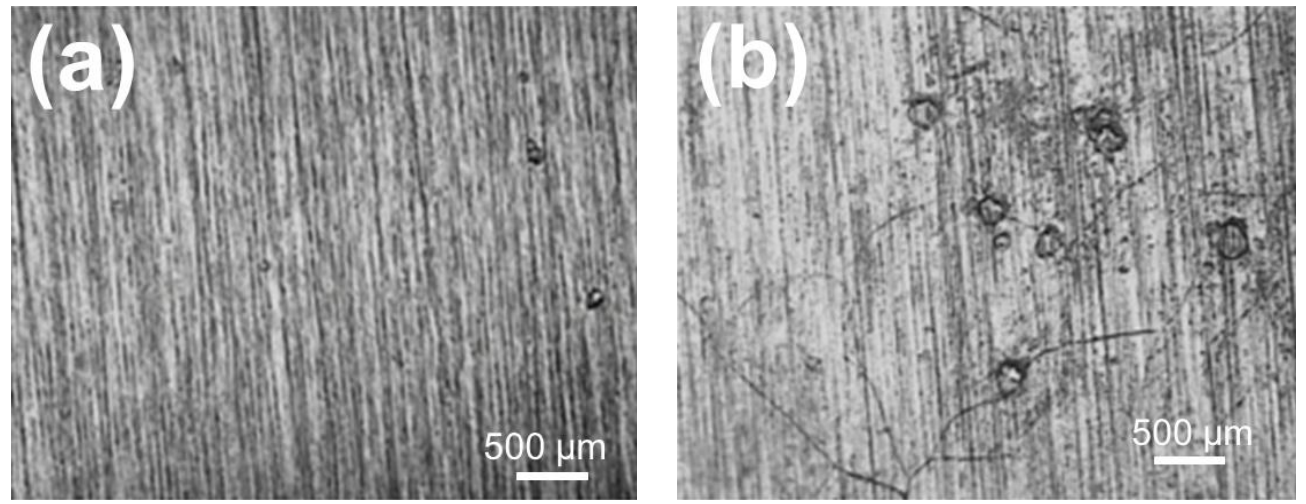

Figure 8. Optical microscopy before and after polarization test: Test specimen with a layer of chromium of $20 \mu \mathrm{m}$ to $22 \mu \mathrm{m}$, (a) before test and (b) after test $100 \times$ magnification
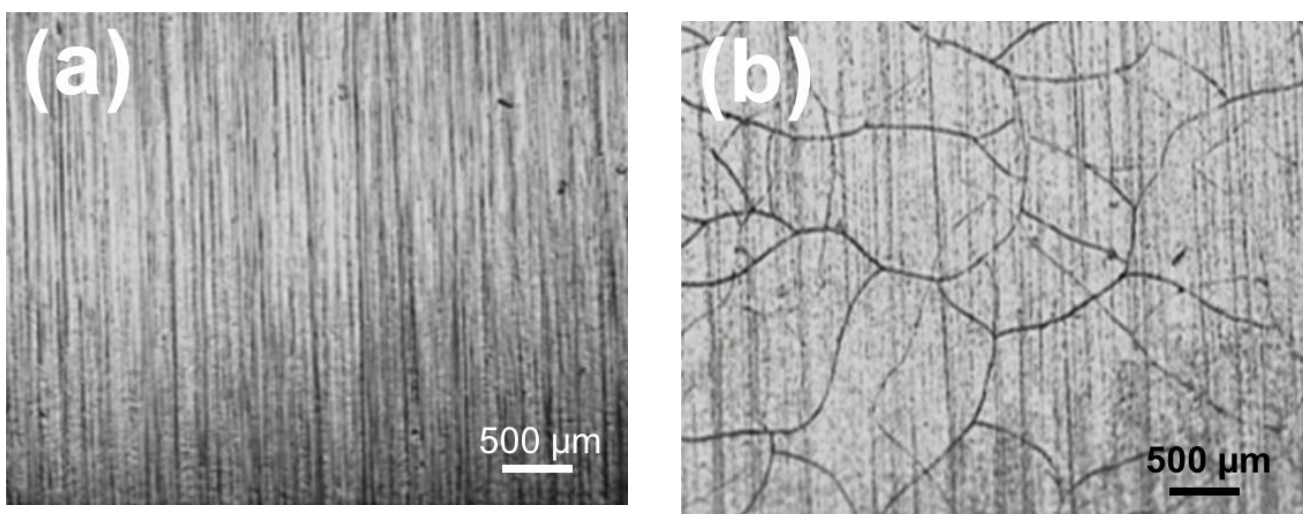

Figure 9. Optical microscopy before and after polarization test: Test specimen with a layer of chromium of $29 \mu \mathrm{m}$ to $34 \mu \mathrm{m}$, (a) before test and (b) after test $100 \times$ magnification

Metallographic characterization reveals and confirms the results above. The images are able to show that the samples with higher chromium layer withstood more attacks and weathering process. These results are consistent results presented by Fredizzi et al. ${ }^{12}$
The results are in agreement with the microscopic images of ${ }^{3-16}$.

The curves obtained in the test "potential vs time" (Figure 10) and the Salt Spray test, also confirm that samples with thicker chromium have better corrosion resistance 
than samples with shorter chromium layer. As the damage occurs in the lining of the natural potential of the chrome that was around -150 $\mathrm{mV}$ (SCE) increased to around $-700 \mathrm{mV}$ (SCE) which is the natural potential of carbon steel, showing that the process is occurring on the steel from corrosion that has been coated.
For El-Amoush et al., ${ }^{3}$ the corrosion resistance is influenced not only by the thickness of the chrome layer but also by the width and depth of the channel of cracks.

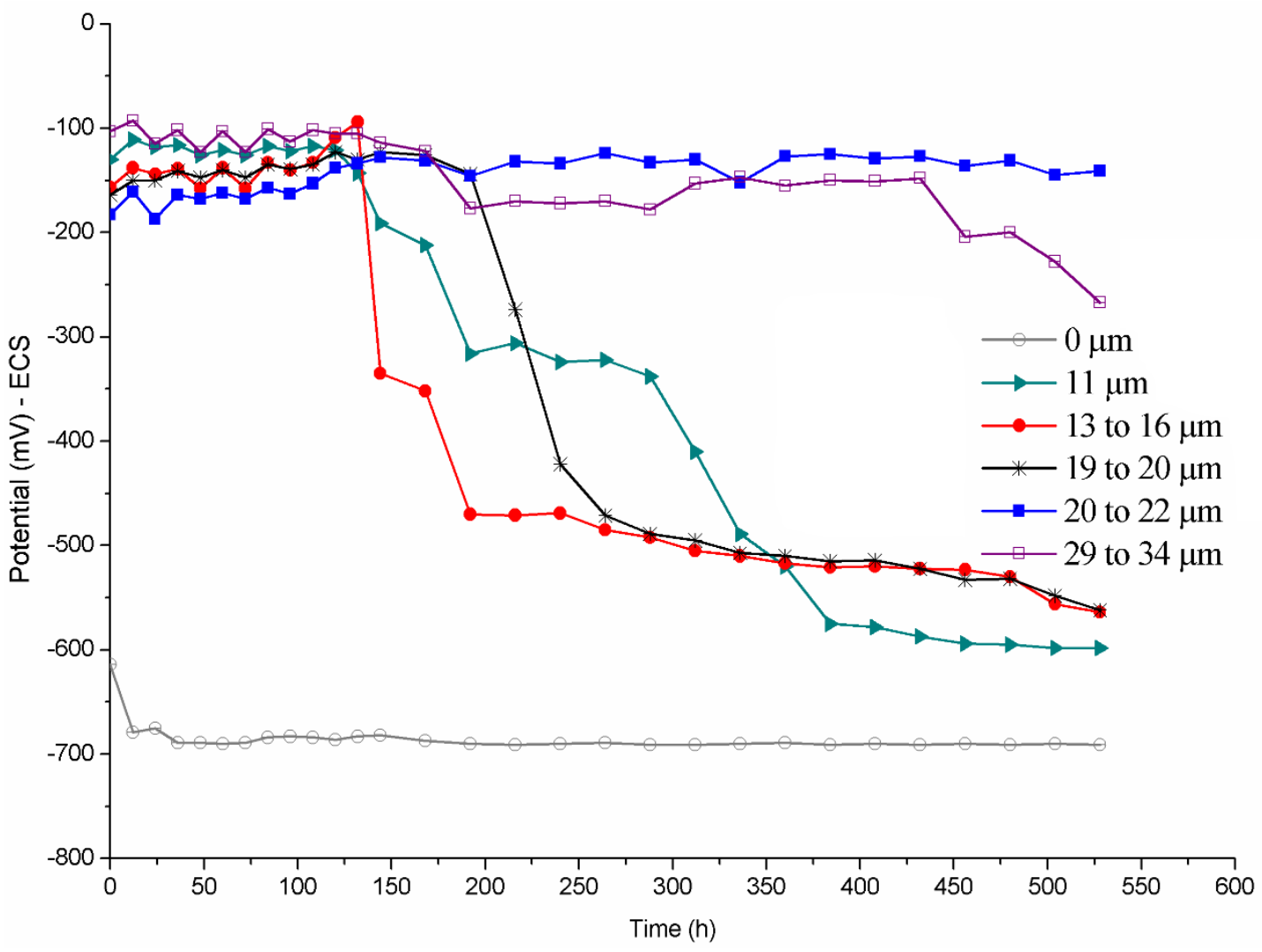

Figure 10. Potential versus time for samples $\mathrm{C} 45 \mathrm{~K}$ steel coated and uncoated chromium in $3.5 \% \mathrm{NaCl}$ solution

\section{Conclusions}

The micro-cracks and defects in coatings of hard chromium favored the inflow of chloride ions causing localized corrosion of the substrate. However, increasing the chromium coating layer provides a higher resistance to penetration of chloride ions, therefore, increases the corrosion resistance of the substrate.

The incidence of micro-cracks may have been the determining factor for chloride ions to cause the passive film to break, causing a pitting corrosion of the substrate.
The samples with greater thicknesses of chromium present a corrosion potential more positive and a lower anodic current density. Corrosion was lower, probably because the chloride had more difficulty of penetrating through the micro-cracks and attack the surface of the substrate metal. Pitting corrosion of the substrate occurs in the anode area, which is located at coating damaged points. These areas are too small in relation to the cathode area, thus there will be accelerated corrosion at these points.

Although some thicknesses have presented good corrosion resistance, after the polarization tests all samples presented an 
increase on the micro-cracks network. It also caused all polarization curves to intersect at the same region of current density, showing that every thickness was damaged by the potential application.

\section{Acknowledgments}

This research was supported by FAPEMIG, CNPq, CAPES and COFAP.

\section{References}

${ }^{1}$ Hongbin, X.; Jianjun, H.; Hui, L.; Rongshan, M.; Fei, S.; Tianfeng, H. Study of Alloying Process on $40 \mathrm{Cr}$ Surface with Electron Beam after Electroplated $\mathrm{Cr}$ Layer. Advances in Materials Science and Engineering, 2013, 2. [CrossRef]

${ }^{2}$ Shan, L.; Zhang, Y.; Wang, Y.; Li, J.; Jiang, X.; Chen, J. Corrosion and wear behaviors of PVD $\mathrm{CrN}$ and $\mathrm{CrSiN}$ coatings in seawater. Transactions of Nonferrous Metals Society of China 2016, 26, 175. [CrossRef]

${ }^{3}$ El-Amoush, A. S.; Abu-Rob, A.; Edwan, H.; Atrash K.; Igab M. Tribological properties of hard chromium coated 1010 mild steel under different sliding distances. Solid State Sciences 2011, 13, 529. [CrossRef]

${ }^{4}$ Koronfel, M. A.; Goode, A. E.; Weker, J. N.; Tay, S. E. R.; Stitt, C. A.; Simoes, T. A.; Mosselmans, J. F. W.; Quinn, P.; Brydson, R.; Hart, A.; Toney, M. F.; Porter, A. E.; Ryan, M. $P$. Understanding the reactivity of CoCrMoimplant wear particles. npj Materials. Degradation 2018, 2, 8. [CrossRef]

${ }^{5}$ Kimbrough, D. E.; Cohen, Y.; Winer, A. M.; Creelman, L.; Mabuni, C. A critical assessment of chromium in the environment. Critical Reviews in Environmental Science and Technology 1999, 29, 1. [CrossRef]

${ }^{6}$ Achmad, R.; Budiawan; Auerkari, E. Effects of Chromium on Human Body. Annual Research \& Review in Biology 2017, 13, 1. [CrossRef]

7 Panossian, Z., Pós-tratamento do revestimento de zinco: PARTE II -
Propriedades da Camada Cromatizada. Tratamento de Superfície 1997, 84, 14. [CrossRef]

${ }^{8}$ Hossein, S.; Soltanieh, M.; Aghajani, H. Repairing the cracks network of hard chromium electroplated layers using plasma nitriding technique. Vaccum 2016, 127, 1. [CrossRef]

${ }^{9}$ Beyragh, M. R. S.; Asl, K. S.; Norouzi, S., A comparative research on corrosion behavior of a standard, crack-free and duplex hard chromium coatings. Surface \& Coatings Technology 2010, 205, 2605 [CrossRef]

${ }^{10}$ Gentil, V.; Corrosão, 5a ed., Livros Técnicos e Científicos Editora: Rio de Janeiro, 2007.

${ }^{11}$ Pardo, A.; Merino, M. C.; Coy, A. E.; Viejo, F.; Arrabal, R.; Matykina, E. Pitting corrosion behaviour of austenitic stainless steels combining effects of $\mathrm{Mn}$ and Mo additions. Corrosion Science 2008, 50, 1796. [CrossRef]

${ }^{12}$ Fedrizzi, L.; Rossi, S.; Bellei, F.; Deflorian, F. Wear-corrosion mechanism of hard chromium coatings. Wear 2002, 253, 1173. [CrossRef]

${ }^{13}$ Zumelzu, E.; Goyos, I.; Cabezas, C.; Opitz, O.; Parada, A. Wear and corrosion behaviour of high-chromium (14-30\% Cr) cast iron alloys. Journal of Materials Processing Technology 2002, 128, 250. [CrossRef]

${ }^{14}$ Hui-Cheng, Y.; Bai-Zhen, C.; Xichang, S.; Xiliang, S.; Bin, L. Investigation of the trivalentchrome coating on 6063 aluminum alloy. Materials Letters 2008, 62, 2828. [CrossRef]

${ }^{15}$ Naiming, L.; Faqin, X.; Jun, Z.; Xiangging, W.; Wei, T. Corrosion Behaviors of P110 Steel and Chromium Coating in CO2-saturated Simulated Oilfield Brine. Journal of Wuhan University of Technology-Mater 2011, 26, 190. [CrossRef]

${ }^{16}$ Zeng, Z.; Liang, A.; Zhang, J. Electrochemical corrosion behavior of chromium-phosphorus coatings electrodeposited from trivalent chromium baths. Electrochim. Acta 2008, 53, 7344. [CrossRef]

${ }^{17}$ Wang, F.; Zhang, F.; Zheng, L.; Zhang, H. Structure and corrosion properties of $\mathrm{Cr}$ coating deposited on aerospace bearing steel. Applied Surface Science 2017, 423, 695. [CrossRef] 